\title{
PREVALENCE OF p21
}

\section{IMMUNOHISTOCHEMICAL EXPRESSION IN ESOPHAGEAL ADENOCARCINOMA}

\author{
Maitê de Mello VILLWOCK ${ }^{1}$, Luise MEURER $^{2}$, Leandro Totti CAVAZZOLA ${ }^{1}$, \\ Richard R. GURSKI ${ }^{1}$, Maria Isabel EDELWEISS ${ }^{2}$ and Carlos Cauduro SCHIRMER ${ }^{1}$
}

\begin{abstract}
Background - In western societies, the prevalence of adenocarcinoma of the gastroesophageal junction has increased in recent years. It is commonly accepted today that esophageal adenocarcinoma develops from a premalignant lesion: Barrett's esophagus. This type of carcinoma is hardly diagnosed at early stages, which results in significant mortality. Molecular biology studies have shown that most malignant tumors originate from the interaction between inherited characteristics and external factors, which may cause genetic changes that interfere with the control over the differentiation and growth of cells in susceptible individuals. p21 (WAF//CIPI) has a key role in the regulation of the cell cycle, and its immunohistochemical expression has been investigated in several tumors, showing that it influences the prognosis of various neoplasms. Aim - To check the prevalence of $\mathrm{p} 21$ protein expression in patients with esophageal adenocarcinoma diagnosed in the last 5 years by the Group for Surgeries of the Esophagus and Stomach of "Hospital de Clínicas de Porto Alegre", RS, Brazil. Methods - The study population consisted of 42 patients with esophageal adenocarcinoma diagnosed by the Group for Surgeries of the Esophagus and Stomach between January 1998 and December 2002. The expression of p21 protein was determined by immunohistochemistry using primary antibody, p21, clone SX118, code M7202 (Dako), and assessed according to the immunoreactive scoring system. Results - Of 42 analyzed patients, $83.3 \%$ were male and older than 40 years. Among these, $56.2 \%$ were submitted to curative resection: total gastrectomy and transhiatal esophagogastrectomy. The remaining patients were submitted to palliative surgery or did not undergo any surgical treatment. Only five patients received adjuvant chemotherapy and radiation therapy, either alone or combined. Advanced disease (stages III and IV) was detected in 78.6\% of the patients. Only nine patients were positive for p21, according to the immunoreactive scoring system. Conclusion - p21 was expressed in 9 of 42 patients (21.4\%) with esophageal adenocarcinoma diagnosed in the last 5 years by the Group for Surgeries of the Esophagus and Stomach of Hospital de Clínicas de Porto Alegre. In our patient population, the accumulation of p21 did not play a key role in the carcinogenesis of esophageal adenocarcinoma.
\end{abstract}

HEADINGS - Esophageal neoplasms. Adenocarcinoma. Cyclin-dependent kinase inhibitor p21.

\section{INTRODUCTION}

In western societies, the prevalence of adenocarcinoma of the gastroesophageal junction has considerably increased in the last years ${ }^{(16,30,35,39)}$, especially compared to the stable or lower incidence of epidermoid carcinoma of the esophagus $^{(9)}$. Such increase corresponds to a rise in the incidence of Barrett's esophagus ${ }^{(16)}$. According to various authors, including Wijnhoven and Jenkins, this increase is larger than in any other malignant neoplasm ${ }^{(16,39)}$.

It is commonly accepted today that esophageal adenocarcinoma originates from a premalignant lesion:
Barrett's esophagus. Barrett's esophagus is a condition in which the normal squamous epithelium of the esophagus is replaced by a columnar epithelium as a result of long-established gastroesophageal reflux, which predisposes the affected individual to the development of adenocarcinoma ${ }^{(8,13,16,21,23,29,39)}$.

Barrett's esophagus is the preliminary step towards esophageal adenocarcinoma. A metaplastic esophagus subsequently progresses to low-grade and high-grade dysplasia, and finally to adenocarcinoma ${ }^{(9,16,29)}$.

Early-stage esophageal carcinoma is often asymptomatic and detection is uncommon. Diagnosis

Divisions of 'General Surgery and ${ }^{2}$ Pathology of "Hospital de Clínicas" Federal University of Rio Grande do Sul, Porto Alegre, RS, Brazil.

Address for correspondence: Dr. Maitê de Mello Villwock - Rua Santa Rita, 285/201 - Floresta - 90220-220 - Porto Alegre, RS, Brasil. E-mail: javillwock@via-rs.net 
is usually established at advanced stages, which results in remarkable mortality ${ }^{(2,13)}$. The large number of patients with advanced disease, combined with poor response to treatment, stresses the necessity to find better tools for early diagnosis and intervention, which may increase the chances of treatment success ${ }^{(9)}$.

It is generally accepted that a multiple-step process of genetic and epigenetic changes causes normal cells to mutate into malignant tumor cells ${ }^{(39)}$. These changes allow the cells to become independent from proliferative regulation and from the cycle of cell death, and also stimulate the proliferative, infiltrative and metastasizing capacities of the cells ${ }^{(39)}$.

The cell cycle: mitosis ( $M$ phase) is the nuclear division process. DNA replication takes place in the $\mathrm{S}$ phase (synthesis). The period between the $\mathrm{M}$ and $\mathrm{S}$ phases is known as $\mathrm{G} 1$, and the period between the end of the $\mathrm{S}$ phase and the beginning of the $\mathrm{M}$ phase is known as the $\mathrm{G} 2$ phase. The cells may exit the cycle and enter the G0 phase, which is a quiescent stage ${ }^{(39)}$.

After DNA damage, the cell cycle arrests at the G1/S or G2/M phase transition, with a $2 \mathrm{~N}$ or $4 \mathrm{~N}$ DNA content, respectively. Arrests at these checkpoints prevent DNA replication and mitosis in the presence of unrepaired chromosome damage ${ }^{(3)}$ Cancer is often described as a cell cycle disease ${ }^{(16)}$. The division of normal cell populations maintains the balance between cellular proliferation and cell $\operatorname{loss}^{(25,39)}$. The progression of cells through different phases of the cell cycle is governed by activated cyclins and cyclin-dependent kinases (CDKs), and CDK inhibitors ${ }^{(12,16,39)}$.

Protein p21 is encoded by WAF1/CIP1 ("wild-type p53 associated fragment $1 / \mathrm{CDK}$-interacting protein 1 "), a tumor suppressor gene located on chromosome $6 \mathrm{p} 21.2^{(17)}$.

Induction of p21 is a common mechanism of growth arrest in different physiological situations. p21 is transiently induced in the course of senescence, or of the genes implicated in age-related diseases (Alzheimer's disease, amyloidosis), reversible and irreversible forms of damage-induced growth arrest, and in the terminal differentiation of postmitotic cells $^{(7,22,34)}$

p21 is a universal CDK inhibitor, binding to all CDK2, CDK3, CDK4 and CDK6 complexes. When p21 forms a quaternary complex with cyclins, CDKs, and proliferating cell nuclear antigen (PCNA), it inhibits the G1/S phase transition ${ }^{(10,14)}$.

Several studies have analyzed the immunohistochemical expression of $\mathrm{p} 21$ in different types of neoplasms.

Some studies have revealed an association of $\mathrm{p} 21$ expression with worse prognosis in breast cancers ${ }^{(4)}$, whereas its lower expression proved to be a worse prognostic factor for carcinomas of the anal canal ${ }^{(15)}$, bladder ${ }^{(20)}$, and ovaries ${ }^{(32)}$.

In normal esophageal squamous epithelium, p21 expression is restricted to the proliferative compartment (basal layer), thus being more highly associated with proliferation than with differentiation $^{(11)}$.

Studies that show an association between p21 and esophageal adenocarcinoma are rare, and the prevalence of the immunohistochemical expression of p21 is still unknown in our setting. Given the epidemiological importance of esophageal adenocarcinoma and the role of p21 in tumorigenesis, the scant data on both, and the search for better prognostic factors, the aim of the present study is to check the prevalence of $\mathrm{p} 21$ expression in patients with esophageal adenocarcinoma treated by the Group for Surgeries of the Esophagus and Stomach of "Hospital de Clínicas" of Porto Alegre (GCEE/HCPA), RS, Brazil, between 1998 and 2002.

\section{PATIENTS AND METHODS}

\section{Patients}

The study population consisted of patients with esophageal adenocarcinoma treated by the GCEE/HCPA between January 1998 and December 2002. We reviewed 63 medical charts of patients diagnosed with esophageal adenocarcinoma and with no history or presence of another concomitant malignant neoplasm, or neoadjuvant treatment (chemotherapy and/or radiation therapy before surgery). Only those patients who had paraffin-embedded biopsies or surgical specimens were included in the study $(n=42)$. The paraffin blocks were analyzed by the Division of Pathology of HCPA.

\section{Immunohistochemical analysis}

The paraffin-embedded biopsies or surgical specimens (representative sections of the tumor) were submitted to the immunohistochemical analysis routinely performed by the Division of Pathology of HCPA, which consisted of deparaffinization and rehydration, antigen retrieval, inactivation of endogenous peroxidase activity and blocking of nonspecific reactions. The primary antibody, $\mathrm{p} 21^{\text {(WAF-1/CIP- }}$ 1), clone SX118, code M7202 (Dako), was incubated for 12 hours at $4^{\circ} \mathrm{C}$, diluted 1:50, followed by the application of streptavidin-biotin-peroxidase complex (LSAB, Dako) and exposed to diaminobenzidine tetrahydrochloride (Kit DAB, Dako) for visualization. Patients with p21-positive breast cancer were used as positive controls, while negative controls did not include the primary antibody.

p21 expression was assessed at the margin of the infiltrative lesion, only in cancer cells, as a nuclear pattern, using the Immunoreactive Scoring System (IRS), used by REMMELE and SCHICKETANZ ${ }^{(28)}$ and cited by HANAS et al. ${ }^{(13)}$ IRS is obtained by multiplying the staining intensity $(0=$ negative, $1=$ weak, 2 $=$ moderate, and $3=$ strong) by the percentage of positive cells $(0=$ negative, $1=10 \%$ positive, $2=11 \%-50 \%$ positive, 3 $=51 \%-80 \%$ positive, and $4=>80 \%$ ). A total of 10 highpower fields are used for each IRS assessment. Scores $\leq 2$ were considered weakly immunopositive, without $\mathrm{p} 21$ overexpression, whilst scores $\geq 3$ were regarded as strongly immunoreactive, with p21 overexpression (Figures 1, 2, 3, 4). Two pathologists who were blinded to the clinical and histopathological information, independently analyzed the glass slides. The final result was obtained through the mean between the pathologists' scores. 


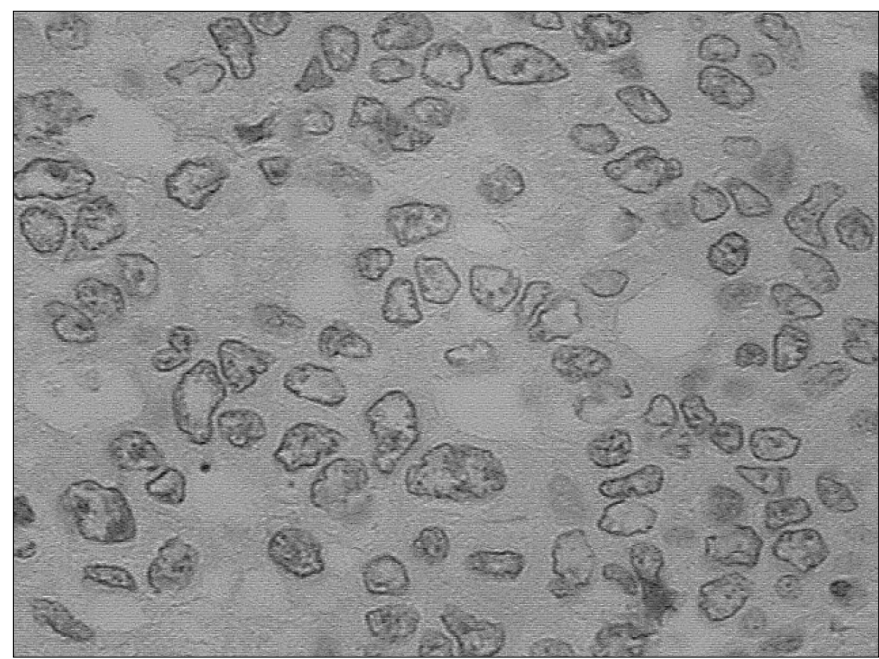

FIGURE 1 - Negative immunohistochemical expression of p21 (400X)

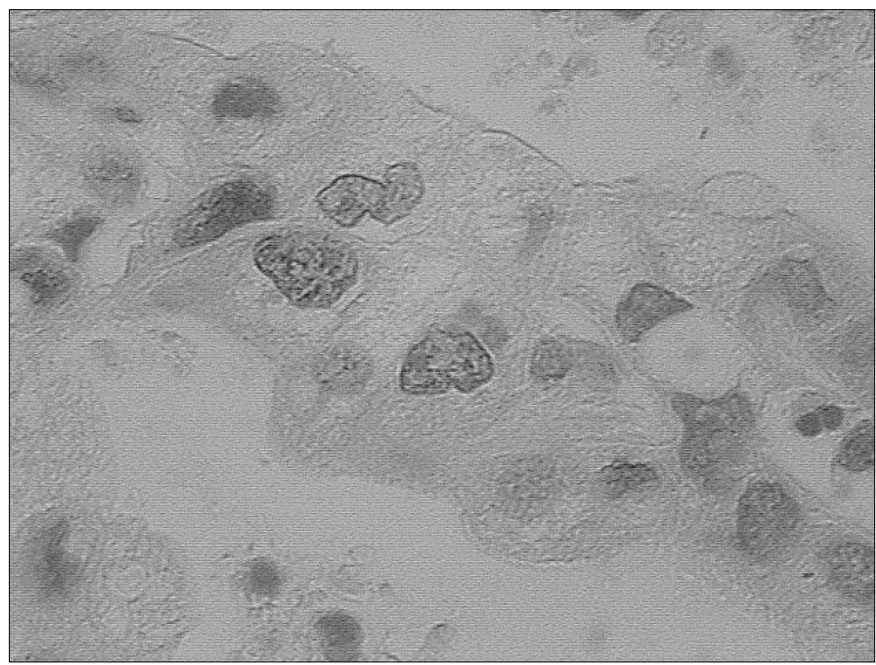

FIGURE 3 - Moderate immunohistochemical expression of p21 (400X)

\section{Study design}

This is a prevalence study, in which the data were collected from the medical charts of patients with esophageal adenocarcinoma treated by the GCEE/HCPA between January 1998 and December 2002.

\section{Statistical analysis}

The quantitative variables were expressed as mean and standard deviation, and the categorical ones expressed as frequency (absolute value) and percentage. Initially, the agreement between the two pathologists regarding the staining intensity and $\mathrm{p} 21$ expression was determined through the intraclass correlation coefficient. The KruskalWallis nonparametric analysis of variance was used to compare the distribution of $\mathrm{p} 21$ in the three groups of histological differentiation. A $P$ value of 0.05 was considered to be statistically significant. The data were processed and analyzed by SPSS (Statistical Package for the Social Sciences) version 10.0 and SigmaPlot version 2.0.

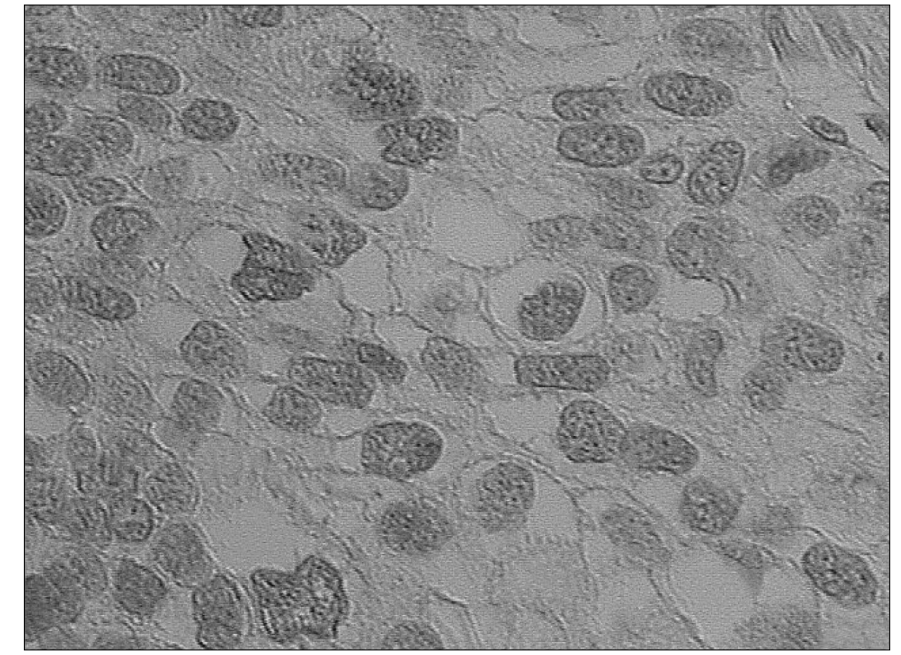

FIGURE 2 - Weak immunohistochemical expression of p21 (400X)

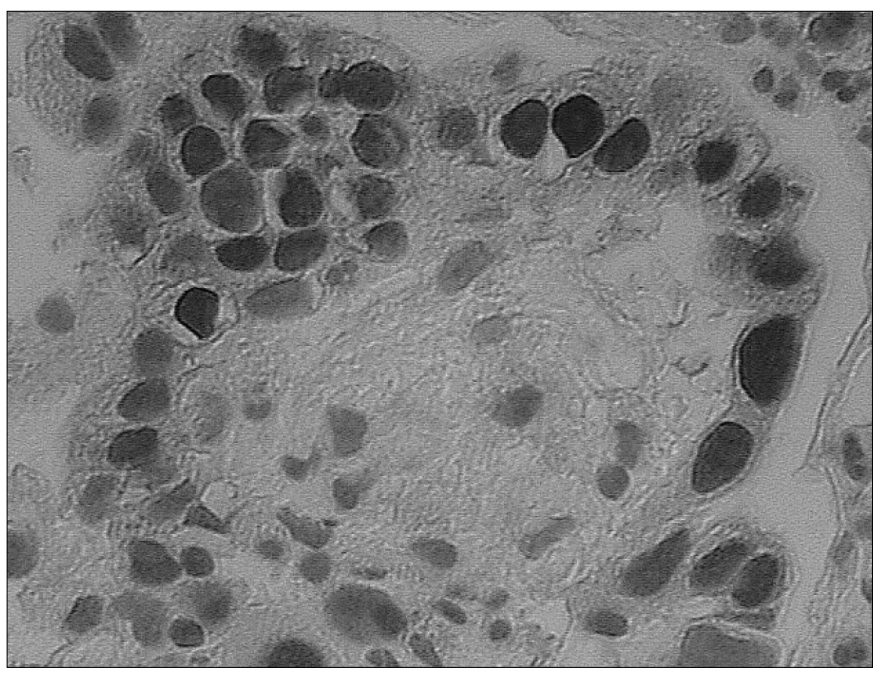

FIGURE 4 - Strong immunohistochemical expression of p21 (400X)

\section{RESULTS}

Most of the 42 patients with esophageal adenocarcinoma diagnosed between January 1st 1998 and December 31st 2002 at the HCPA, and treated by the GCEE, were male and older than 40 years.

Total gastrectomy and transhiatal esophagogastrectomy were performed in $56.2 \%$ of the patients, whereas the remaining patients were submitted to palliative surgery or did not undergo any surgical treatment. Only five patients received adjuvant chemotherapy and radiation therapy, either alone or combined. Approximately $78.6 \%$ of the patients had advanced disease, stages III and IV (Table 1).

Among the 42 studied patients, 9 were positive for $\mathrm{p} 21$, according to the immunoreactivity score (p21+ $\geq 3$ ) (Figure 5).

The inter-observer agreement was estimated through the intraclass correlation coefficient, which was 0.96 for both the 
staining intensity and percentage of p21-positive cells per highpower field, with a statistical significance of $P<0.001$; and 0.94 for the immunoreactivity score of $\mathrm{p} 21$, with $P<0.001$; showing broad agreement between the observers.

p21 $1^{\text {(WAF1/CIP1) }}$ expression was not correlated with the degrees of histological differentiation of the biopsies and surgical specimens (Figure 6).

TABLE 1 - Characteristics of patients with esophageal adenocarcinoma diagnosed between 1998 and 2002 at HCPA, $\mathrm{n}=42$

\begin{tabular}{lc}
\hline \multicolumn{1}{c}{ Characteristic } & Summary measure \\
\hline Age (years) & $62.3 \pm 9.9$ \\
Gender M/F, (\%) & $83.3 / 16.7$ \\
Stage & \\
I & $3(7.1)$ \\
II & $6(14.3)$ \\
III & $22(52.4)$ \\
IV & $11(26.2)$ \\
Procedure & \\
Total gastrectomy & $13(31.0)$ \\
Palliative surgery & $12(28.6)$ \\
Transhiatal resection & $11(25.2)$ \\
Biopsy & $6(14.3)$ \\
Adjuvant therapy, n $(\%)$ & $5(11.9)$ \\
\hline
\end{tabular}

The data are expressed as mean \pm standard deviation or number (percentage)

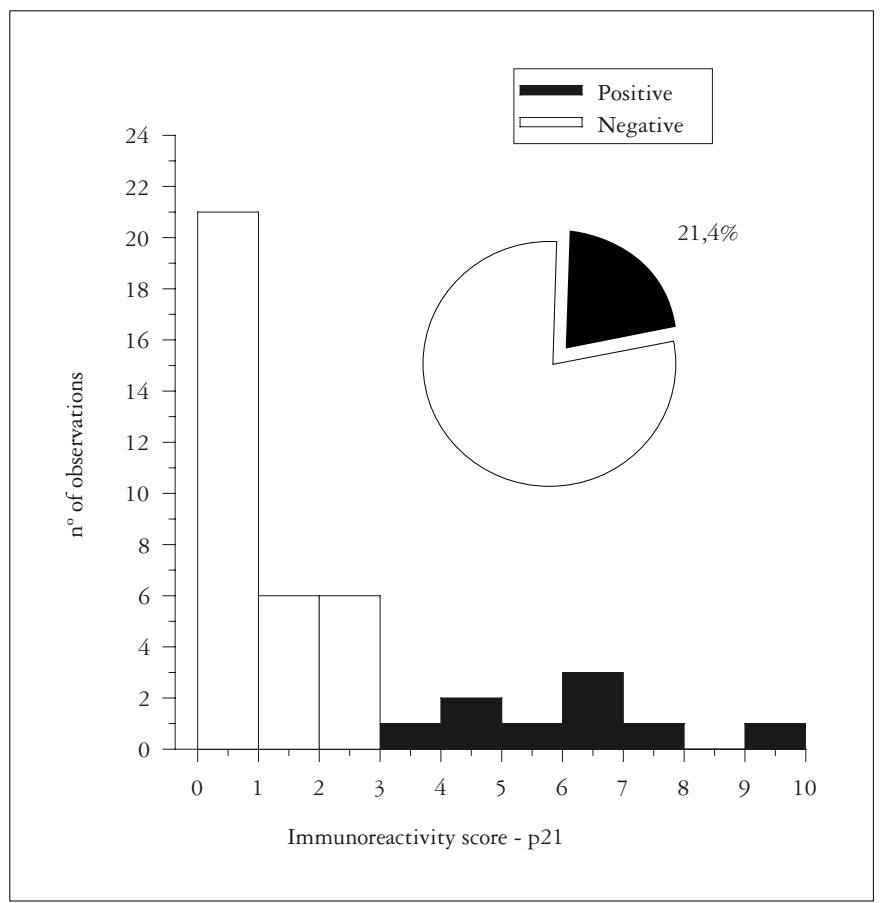

FIGURE 5 - Frequency distribution of p21 and number of observations with positive expression (score $\geq 3$ ) in patients with of esophageal adenocarcinoma identified between 1998 and 2002 at HCPA, $\mathrm{n}=42$ (95\% CI: 11 to 35.7$)$

\section{DISCUSSION}

The esophagus usually has a squamous epithelium. The most common histological type of esophageal cancer is the squamous cell carcinoma or epidermoid carcinoma; historically, adenocarcinoma is less frequent ${ }^{(27)}$. However, several studies have shown that the incidence of adenocarcinoma has been increasing in western countries ${ }^{(5,27,36,37)}$, whereas the incidence of epidermoid carcinoma has remained relatively stable ${ }^{(36)}$. The reason why such increase occurs is controversial; according to some authors, the lower prevalence of Helicobacter pylori infection, which seems to be a protective factor, and the higher prevalence of obesity, increased fat intake, and smoking may be involved ${ }^{(5,36)}$. Smoking and alcoholism are etiologic factors in epidermoid carcinoma of the esophagus ${ }^{(36)}$.

Epidermoid carcinoma and esophageal adenocarcinoma are frequently described in the literature as a single disease of the esophagus, probably because the surgical procedures are similar ${ }^{(1)}$. It is still unclear whether histological types differ as to location only or as to biological behavior as well ${ }^{(1)}$.

Barrett's esophagus is a premalignant condition associated with gastroesophageal reflux, where the esophageal squamous epithelium is replaced by a metaplastic columnar epithelium ${ }^{(37)}$. Gastroesophageal reflux has been suggested as an etiologic factor for adenocarcinoma and gastric cardia cancer as well ${ }^{(36)}$, which results in their being studied as a single entity ${ }^{(27)}$. The study conducted by WIJNHOVEN et al. ${ }^{(38)}$ showed that patients with carcinomas

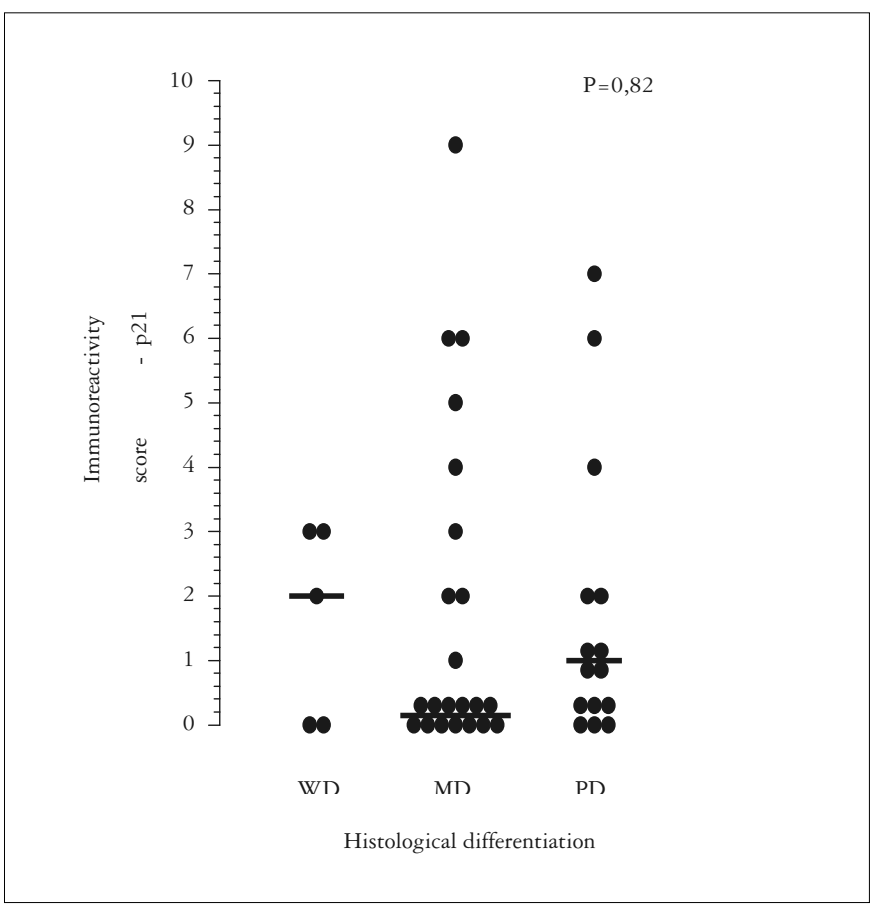

FIGURE 6 - Distribution of immunoreactivity score values of p21 in patients with of esophageal adenocarcinoma according to histological differentiation (WD: well differentiated; MD: moderately differentiated; PD: poorly differentiated) identified between 1998 and 2002 at HCPA, $n=42$ 
of the gastric cardia shared common characteristics, such as age, sexual distribution (male predominance) and histological findings, with patients with esophageal adenocarcinoma, and that, these diseases should therefore be regarded as a single entity, especially because carcinoma of the gastric cardia revealed remarkable differences when compared to noncardial gastric carcinoma. On the other hand, although WEISS et al. ${ }^{(36)}$ consider carcinoma of the gastric cardia and esophageal adenocarcinoma to be virtually identical and clearly different forms of epidermoid carcinoma, they advocate that they should be regarded as clinically distinct entities. The epidemiological profile of patients in the present study is similar to that of other reference centers around the world, which also have reported a predominance of male individuals $(83.3 \%)$ aged above 60 years old (mean age of 62.3 years).

The assessment of Barrett's esophagus, which is associated with a greater risk for adenocarcinoma ${ }^{(5)}$, is impaired in these patients due to the extension of the disease at diagnosis $(78.6 \%$ of patients with stages III and IV disease), where the mucous membrane with metaplastic lesions may be totally affected by tumor progression ${ }^{(31)}$.

A great deal of effort has been channeled into finding biomarkers that can influence the progression of Barrett's esophagus in the metaplasia-dysplasia-adenocarcinoma sequence. At the GCEE/HCPA, CAVAZZOLA ${ }^{(6)}$ assessed the expression of p53 and VEGF (vascular endothelial growth factor) in 46 patients with esophageal adenocarcinoma. p53 and VEGF were expressed in $52.2 \%$ and $47.8 \%$ of the tumors, respectively, coinciding in $26 \%$ of the cases, but no association with this expression was established. The expressions of p53 and VEGF were not correlated with prognosis in patients with esophageal adenocarcinoma submitted to curative resection.

p21 is a CDK inhibitor, which inhibits the G1/S phase transition ${ }^{(10)}$. In human cells, p21 is considered a major factor in the up-regulation of the nuclear expression of $\mathrm{p} 53^{(10)} \cdot \mathrm{p} 21$ has been expressed in several malignant neoplasms, including esophageal adenocarcinomas ${ }^{(8,13,23)}$.

p21 expression also varies considerably in adenocarcinoma and epidermoid carcinoma of the esophagus (Table 2). SETA et al. ${ }^{(33)}$ found an expression of $27 \%$, whereas SHIRAKAWA et al. ${ }^{(34)}$ found an expression of 59\% in superficial epidermoid carcinomas. According to SHIRAKAWA et al. ${ }^{(34)}, \mathrm{p} 21$ expression was correlated with the degree of histological differentiation of the tumor. The expression of p21 was high in $8(100 \%)$ of 8 well-differentiated and in $4(57 \%)$ of 7 moderately differentiated cases, but weak in $4(40 \%)$ of 10 poorly differentiated cases. NATSUGOE et al. ${ }^{(24)}$ found a 21 expression of $43.2 \%$ (48 of 111 patients) in epidermoid carcinomas of the esophagus at advanced stages of the disease. The same authors used multivariate analysis and found that $\mathrm{p} 21$ expression in the p53-dependent pathway was an independent prognostic factor ${ }^{(24)}$. The expression of $\mathrm{p} 21$ was detected in $44 \%$ ( 11 of 25 patients) with epidermoid carcinoma of the esophagus, with a percentage of positive cells between $1 \%$ and $10 \%$ in the study carried out by OHASHI et al. ${ }^{(26)}$. The same study also showed a good correlation between expression and the degree of histological differentiation. Of 8 well-differentiated cases, $6(67 \%)$ were positive, whereas all of the poorly differentiated cases(8) were negative ${ }^{(26)}$. NITA el al. ${ }^{(25)}$ studied p21 expression (14\%) as a prognostic marker in curatively resected esophageal squamous cell carcinoma. They found a 5-year survival rate for high $\mathrm{p} 21$ expression group of $68 \%$, and $31 \%$ in the low expression group $(P=0.0062)$, when this groups were compared with lymph node involvement, the survival curves were significantly different $(P$ $=0.0017$ ). Thus, $\mathrm{p} 21$ expression was an independent prognostic factor in curatively resected esophageal squamous cell carcinoma. MEURER $^{(19)}$, who studied patients with epidermoid carcinoma of the esophagus, found a $\mathrm{p} 21$ expression of $77.1 \%$, which was not related to the survival of patients submitted to surgery.

According to LIU et al. ${ }^{(18)}$, in gastric adenocarcinoma, $\mathrm{p} 21^{\text {(WAF1/CIP1) }}$ was expressed in $40 \%$ of the patients, and its expression was considered a positive prognostic factor.

In the study conducted by MOSKALUK et al. ${ }^{(23)}, 66 \%$ (58 of 88 patients) of esophageal adenocarcinomas showed a weak p21 expression ( $<25 \%$ of positive cells), only $9(10 \%)$ adenocarcinomas revealed a diffuse p 21 expression (less than $50 \%$ of positive cells). The comparison of the same tumor areas with p53 and p 21 expression showed discrepant results in most cases; therefore, it is believed that $\mathrm{p} 21$ expression is independent of $\mathrm{p} 53$ protein $^{(23)}$. According to HANAS et al. ${ }^{(13)}$, an overexpression of $\mathrm{p} 21$ was observed in a small series of three patients with adenocarcinoma. And to CHATELAIN et al. ${ }^{(8)}$, in another small series, p21 was overexpressed in 2 superficial adenocarcinomas, and in most cases, p21 expression was not related to p53 expression.

TABLE 2 - Similarities and differences of p21 in squamous cell esophageal cancer and esophageal adenocarcinoma

\begin{tabular}{|c|c|c|c|c|c|}
\hline \multicolumn{6}{|c|}{ p21 Expression } \\
\hline \multicolumn{3}{|c|}{ Squamous cell cancer } & \multicolumn{3}{|c|}{ Esophageal adenocarcinoma } \\
\hline Study & Expression & Observation & Study & Expression & Observation \\
\hline $\begin{array}{l}\text { Ohashi } \\
(1997)\end{array}$ & $44 \%$ & $\begin{array}{l}\text { Showed a good } \\
\text { correlation between } \\
\text { expression and the } \\
\text { degree of histological } \\
\text { differentiation }\end{array}$ & $\begin{array}{c}\text { Moskaluk } \\
(1996)\end{array}$ & $\begin{array}{l}66 \% \\
9 \%\end{array}$ & $\begin{array}{c}\text { weak } \\
\text { expression } \\
\text { diffuse } \\
\text { expression }\end{array}$ \\
\hline $\begin{array}{l}\text { Seta } \\
(1998)\end{array}$ & $27 \%$ & & $\begin{array}{l}\text { Hanas } \\
(1999)\end{array}$ & Overexpression & $\begin{array}{l}\text { in a small } \\
\text { series of three } \\
\text { patients }\end{array}$ \\
\hline $\begin{array}{l}\text { Natsugoe } \\
\text { (1999) }\end{array}$ & $43 \%$ & $\begin{array}{l}\text { At advanced stages } \\
\text { of the disease }\end{array}$ & $\begin{array}{l}\text { Chatelain } \\
(2003)\end{array}$ & Overexpression & $\begin{array}{c}\text { in } 2 \text { superficial } \\
\text { adenocarcinomas } \\
\text { and p21 } \\
\text { expression was } \\
\text { not related to } \\
\text { p53 expression }\end{array}$ \\
\hline $\begin{array}{l}\text { Nita } \\
\text { (1999) }\end{array}$ & $14 \%$ & $\begin{array}{l}\text { Prognostic marker } \\
\text { in curatively } \\
\text { resected esophageal } \\
\text { squamous cell } \\
\text { carcinoma }\end{array}$ & & & \\
\hline $\begin{array}{l}\text { Shirakawa } \\
(2000)\end{array}$ & $59 \%$ & $\begin{array}{l}\text { In superficial } \\
\text { epidermoid } \\
\text { carcinomas }\end{array}$ & & & \\
\hline $\begin{array}{l}\text { Meurer } \\
(2003)\end{array}$ & $77,1 \%$ & $\begin{array}{l}\text { Was not related } \\
\text { to the survival of } \\
\text { patients submitted } \\
\text { to surgery }\end{array}$ & & & \\
\hline
\end{tabular}




\section{CONCLUSION}

In the present study, we decided to use an immunoreactivity score to evaluate the expression of $\mathrm{p} 21$, since evaluation methods vary in different studies. p21 was expressed in 9 of $42(21.4 \%)$ patients with adenocarcinoma of the gastroesophageal junction included in the study, a result that is quite different from other studies on adenocarcinoma, probably because the method used to determine $\mathrm{p} 21$ expression varies among studies. No correlation was found as to the degree of histological differentiation of the tumor as described in some studies on epidermoid carcinoma of the esophagus ${ }^{(26,34)}$.

Villwock MM, Meurer L, Cavazzola LT, Gurski RR, Edelweiss MI, Schirmer CC. Prevalência da expressão imunoistoquímica da proteína p21 em adenocarcinoma do esôfago. Arq Gastroenterol. 2006;43(3):212-8.

RESUMO - Racional - No mundo ocidental, a prevalência de adenocarcinoma da junção esôfago-gástrica vem crescendo nas últimas décadas. Atualmente, é aceito que o adenocarcinoma do esôfago se desenvolve de uma lesão pré-maligna: esôfago de Barrett. Este carcinoma é de difícil diagnóstico nos seus estágios iniciais, o que resulta em mortalidade significativa. $\mathrm{O}$ estudo da biologia molecular tem demonstrado que grande parte dos tumores malignos tem origem na interação entre o componente hereditário e influências externas, que em indivíduos predispostos podem ocasionar alterações genéticas que influenciem o controle da diferenciação e crescimento celular. O p2 $1^{(\mathrm{WAF} / / \mathrm{CIPI})}$ tem papel fundamental na regulação do ciclo celular e sua expressão imunoistoquímica tem sido estudada em diversos tumores, mostrando influência no prognóstico de várias neoplasias. Objetivo - Verificar a prevalência da expressão da proteína p21 em pacientes com adenocarcinoma de esôfago diagnosticados nos últimos 5 anos no Grupo de Cirurgia de Esôfago e Estômago do Hospital de Clínicas de Porto Alegre, RS (GCEE/HCPA). Pacientes e Métodos - A população em estudo foi constituída de 42 pacientes com adenocarcinoma de esôfago diagnosticados no GCEE/HCPA entre janeiro de 1998 e dezembro de 2002. A expressão da proteína p21 foi avaliada por meio de imunoistoquímica, com anticorpo primário, p21, clone SX118, código M7202 da DAKO, e quantificada de acordo com o sistema de escore de imunorreatividade ("Immunoreactive scoring system" - IRS). Resultados - Foram estudados 42 pacientes, 83,3\% eram do sexo masculino, com idade superior a 40 anos. Destes, $56,2 \%$ foram submetidos a procedimentos cirúrgicos com intenção curativa: gastrectomia total e esofagogastrectomia transhiatal. Os demais foram submetidos a cirurgia paliativa ou não sofreram tratamento cirúrgico. Apenas cinco pacientes receberam tratamento adjuvante com quimioterapia e radioterapia, isoladas ou combinadas. Quanto ao estádio, 78,6\% dos pacientes apresentavam doença avançada, estádios III e IV. Apenas nove apresentaram positividade para o p21, quando considerado o IRS. Conclusão - A proteína p21 esteve expressa em 9 dos 42 pacientes $(21,4 \%)$ com adenocarcinoma de esôfago diagnosticados nos últimos 5 anos no GCEE/HCPA. Nessa casuística, o acúmulo de p21 não se mostrou essencial no processo de carcinogênese do adenocarcinoma esofágico.

DESCRITORES - Neoplasia esofágicas. Adenocarcinoma. Inibidor de quinase depedendente de ciclina p21. 


\section{REFERENCES}

1. Alexandrou A, Davis PA, Law S, Murthy S, Whooley BP, Wong J. Squamous cell carcinoma and adenocarcinoma of the lower third of the esophagus and gastric cardia: similarities and differences. Dis Esophagus. 2002;15:290-5

2. Aloia TA, Harpole DH Jr., Reed CE, Allegra C, Moore MB, Herndon JE, D’Amico TA. Tumor marker expression is predictive of survival in patients with esophagea cancer. Ann Thorac Surg. 2001;72:859-66.

3. Bunz F, Dutriaux A, Lengauer C, Waldman T, Zhou S, Brown JP, Sedivy JM, Kinzler $\mathrm{KW}$, Vogelstein B. Requirement for p53 and p21 to sustain G2 arrest after DNA damage. Science. 1998;282:1497-501.

4. Caffo O, Doglioni C, Veronese S, Bonzanini M, Marchetti A, Buttitta F, Fina P, Leek R, Morelli L, Palma PD, Harris AL, Barbareschi M. Prognostic value of p21(WAF1) and p53 expression in breast carcinoma: an immunohistochemical study in 261 patients with long-term follow-up. Clin Cancer Res. 1996;2:1591-9.

5. Cameron AJ. Epidemiology of Barrett's esophagus and adenocarcinoma. Dis Esophagus. 2002;15:106-8.

6. Cavazzola LT. Avaliação da expressão da proteína p 53 e do VEGF (fator de cresciment do endotélio vascular) em pacientes com adenocarcinoma do esôfago [tese]. Porto Alegre: Faculdade de Medicina da Universidade Federal do Rio Grande do Sul; 2004.

7. Chang BD, Watanabe K, Broude EV, Fang J, Poole JC, Kalinichenko TV, Roninson IB. Effects of p21Waf1/Cip1/Sdil on cellular gene expression: implications for carcinogenesis, senescence, and age-related diseases. Proc Natl Acad Sci U S A. 2000;97:4291-6.

8. Chatelain D, Flejou JF. High-grade dysplasia and superficial adenocarcinoma in Barrett's esophagus: histological mapping and expression of p53, p21 and Bcl-2 oncoproteins. Virchows Arch. 2003;442:18-24.

9. Corley DA, Levin TR, Habel LA, Weiss NS, Buffler PA. Surveillance and surviva in Barrett's adenocarcinomas: a population-based study. Gastroenterology. 2002;122:633-40.

10. el Deiry WS, Tokino T, Velculescu VE, Levy DB, Parsons R, Trent JM, Lin D, Mercer WE, Kinzler KW, Vogelstein B. WAF1, a potential mediator of p53 tumor suppression. Cell. 1993;75:817-25.

11. el Deiry WS, Tokino T, Waldman T, Oliner JD, Velculescu VE, Burrell M, Hill DE Healy E, Rees JL, Hamilton SR. Topological control of p21WAF1/CIP1 expression in normal and neoplastic tissues. Cancer Res. 1995;55:2910-9.

12. Gartel AL, Serfas MS, Tyner AL. p21--negative regulator of the cell cycle. Proc Soc Exp Biol Med. 1996;213:138-49.

13. Hanas JS, Lerner MR, Lightfoot SA, Raczkowski C, Kastens DJ, Brackett DJ, Postie RG. Expression of the cyclin-dependent kinase inhibitor p21(WAF1/CIP1) and p53 tumor suppressor in dysplastic progression and adenocarcinoma in Barrett esophagus. Cancer. 1999;86:756-63.

14. Harper JW, Adami GR, Wei N, Keyomarsi K, Elledge SJ. The p21 Cdk-interacting protein Cip1 is a potent inhibitor of G1 cyclin-dependent kinases. Cell. 1993;75:805-16.

15. Holm R, Skovlund E, Skomedal H, Florenes VA, Tanum G. Reduced expression of p21WAF1 is an indicator of malignant behaviour in anal carcinomas. Histopathology. 2001;39:43-9.

16. Jenkins GJ, Doak SH, Parry JM, D'Souza FR, Griffiths AP, Baxter JN. Genetic pathways involved in the progression of Barrett's metaplasia to adenocarcinoma. $\mathrm{Br}$ J Surg. 2002;89:824-37.

17. Lam KY, Law S, Tin L, Tung PH, Wong J. The clinicopathological significance of p21 and p53 expression in esophageal squamous cell carcinoma: an analysis of 153 patients. Am J Gastroenterol. 1999;94:2060-8.

18. Liu XP, Kawauchi S, Oga A, Suehiro Y, Tsushimi K, Tsushimi M, Sasaki K. Combined examination of $\mathrm{p} 27(\mathrm{Kip} 1), \mathrm{p} 21$ (Waf1/Cip1) and $\mathrm{p} 53$ expression allows precise estimatio of prognosis in patients with gastric carcinoma. Histopathology. 2001;39:603-10.

19. Meurer L. Densidade microvascular intratumoral e expresão imuno-histoquímica de p21: associação com sobrevida em pacientes submetidos a cirurgia por carcinoma epidermóide de esôfago [tese]. Porto Alegre: Faculdade de Medicina da Universidade Federal do Rio Grande do Sul; 2003.

20. Migaldi M, Sgambato A, Garagnani L, Ardito R, Ferrari P, De Gaetani C, Cittadin A, Trentini GP. Loss of $\mathrm{p} 21 \mathrm{Waf} 1$ expression is a strong predictor of reduced survival in primary superficial bladder cancers. Clin Cancer Res. 2000;6:3131-8.
21. Moraes-Filho J, Cecconello I, Gama-Rodrigues J, Castro L, Henry MA, Meneghelli UG, Quigley E. Brazilian consensus on gastroesophageal reflux disease: proposals for assessment, classification, and management. Am J Gastroenterol. 2002;97:241-8

22. Morisaki H, Ando A, Nagata Y, Pereira-Smith O, Smith JR, Ikeda K, Nakanishi M. Complex mechanisms underlying impaired activation of Cdk 4 and $\mathrm{Cdk} 2$ in replicative senescence: roles of p16, p21, and cyclin D1. Exp Cell Res. 1999;253:503-10.

23. Moskaluk CA, Heitmiller R, Zahurak M, Schwab D, Sidransky D, Hamilton SR. p53 and 2 1(WAF1/CIP1/SDI) gene products in Barrett esophagus and adenocarcinoma of the esophagus and esophagogastric junction. Hum Pathol. 1996;27:1211-20.

24. Natsugoe $S$, Nakashima S, Matsumoto M, Xiangming C, Okumura H, Kijima F, Ishigam S, Takebayashi Y, Baba M, Takao S, Aikou T. Expression of p21WAF1/Cip1 in the p53-dependent pathway is related to prognosis in patients with advanced esophageal carcinoma. Clin Cancer Res. 1999;5:2445-9.

25. Nita ME, Nagawa H, Tominaga O, Tsuno N, Hatano K, Kitayama J, Tsuruo T, Domene CE, Muto T. p21Waf1/Cip1 expression is a prognostic marker in curatively resected esophageal squamous cell carcinoma, but not p27Kip1, p53, or Rb. Ann Surg Oncol. 1999;6:481-8.

26. Ohashi K, Nemoto T, Eishi Y, Matsuno A, Nakamura K, Hirokawa K. Expression of the cyclin dependent kinase inhibitor p21WAF1/CIP1 in oesophageal squamous cell carcinomas. Virchows Arch. 1997;430:389-95.

27. Pera M, Cameron AJ, Trastek VF, Carpenter HA, Zinsmeister AR. Increasing incidence of adenocarcinoma of the esophagus and esophagogastric junction. Gastroenterology. 1993;104:510-3.

28. Remmele W, Schicketanz KH. Immunohistochemical determination of estrogen and progesterone receptor content in human breast cancer. Computer-assisted image analysis (QIC score) vs. subjective grading (IRS). Pathol Res Pract. 1993;189:862-6.

29. Riegman PH, Vissers KJ, Alers JC, Geelen E, Hop WC, Tilanus HW, van Dekken H. Genomic alterations in malignant transformation of Barrett's esophagus. Cancer Res. 2001;61:3164-70

30. Rudiger SJ, Feith M, Werner M, Stein HJ. Adenocarcinoma of the esophagogastric junction: results of surgical therapy based on anatomical/topographic classification in 1,002 consecutive patients. Ann Surg. 2000;232:353-61.

31. Ruol A, Parenti A, Zaninotto G, Merigliano S, Costantini M, Cagol M, Alfieri R, Bonavina L, Peracchia A, Ancona E. Intestinal metaplasia is the probable common precursor of adenocarcinoma in Barrett esophagus and adenocarcinoma of the gastric cardia. Cancer. 2000;88:2520-8

32. Schmider A, Gee C, Friedmann W, Lukas JJ, Press MF, Lichtenegger W, Reles A. p21 (WAF1/CIP1) protein expression is associated with prolonged survival but not with p53 expression in epithelial ovarian carcinoma. Gynecol Oncol. 2000;77:237-42.

33. Seta T, Imazeki F, Yokosuka O, Saisho H, Suzuki T, Koide Y, Isono K. Expression of p53 and p21WAF1/CIP1 proteins in gastric and esophageal cancers: comparison with mutations of the p53 gene. Dig Dis Sci. 1998;43:279-89.

34. Shirakawa Y, Naomoto Y, Kimura M, Kawashima R, Yamatsuji T, Tamaki T, Hamada M, Haisa M, Tanaka N. Topological analysis of p21WAF1/CIP1 expression in esophageal squamous dysplasia. Clin Cancer Res. 2000;6:541-50.

35. Siewert JR, Stein HJ. Classification of adenocarcinoma of the oesophagogastric junction. Br J Surg. 1998;85:1457-9.

36. Weiss MM, Kuipers EJ, Hermsen MA, van Grieken NC, Offerhaus J, Baak JP, Meuwissen SG, Meijer GA. Barrett's adenocarcinomas resemble adenocarcinomas of the gastric cardia in terms of chromosomal copy number changes, but relate to squamous cell carcinomas of the distal oesophagus with respect to the presence of high-level amplifications. J Pathol. 2003;199:157-65.

37. Whittles CE, Biddlestone LR, Burton A, Barr H, Jankowski JA, Warner PJ, Shepherd NA. Apoptotic and proliferative activity in the neoplastic progression of Barrett's oesophagus: a comparative study. J Pathol. 1999;187:535-40.

38. Wijnhoven BP, Siersema PD, Hop WC, van Dekken H, Tilanus HW. Adenocarcinomas of the distal oesophagus and gastric cardia are one clinical entity. Rotterdam Oesophageal Tumour Study Group. Br J Surg. 1999;86:529-35.

39. Wijnhoven BP, Tilanus HW, Dinjens WN. Molecular biology of Barrett's adenocarcinoma. Ann Surg. 2001;233:322-37.

Recebido em 17/9/2004. Reapresentado em 15/3/2006. Aprovado em 29/3/2006. 